\title{
教育心理 学関係
}

\section{博士 論 文要旨}

(2009年10月～2010年 9 月)

ここに揭載する博士論文要旨は，1996年から自己申告によるものとなりました。

\section{筑波大学大学院人間総合科学研究科}

\section{博士（カウンセリング科学）家近 早苗}

「心理教育的援助サービスの向上に影響を与えるコー ディネーション委員会の機能」

コーディネーション委員会の機能と教師の意識の変化, 教師の心理教育的援助サービスとの関連，生徒が受ける 心理教育的援助サービスについて検討した。その結果, コーディネーション委員会の機能は，教師の意識の変化， 援助に関する当事者としての態度を通して教師の心理教 育的援助サービスに影響を与えること，コーディネー ション委員会の機能は, 直接, 教師の心理教育的援助 サービスに影響を与えることが明らかになった。

\section{筑波大学大学院人間総合科学研究科}

\section{博士（学術）小野寺 正己}

「中学生の学級への適応感を高めるグループ・アプローチ に関する研究」

本論文は，中学生の学級への適応感を高めることを目 的としたグループ・アプローチについて検討した。はじ めに，心理尺度の調査結果を基にグループ・アプローチ のモデルを検討した結果, 「学級内でのソーシャル・スキ ルの影響を受けた自己開示を行うことが学級への適応感 を高める」というモデルが作成された。この結果を受け， 作成したモデルに基づいたグループ・アプローチを実践 した結果，モデルの妥当性が示唆された。

\section{筑波大学大学院人間総合科学研究科}

\section{博士（心理学） 上村 惠津子}

「保護者面談に抢ける教師の連携促進プロセスに関する 研究」

本研究では，保護者面談で教師が保護者との連携を促 進するプロセスを検討した。教師および保護者の発話と その相互作用を分析した結果, 教師の発話には, 面談目 的が曖昧である反面, 自らの対応を振り返り具体的な対 応策を積極的に提案する特徵があることが明らかになっ た。また，振り返りや葛藤のような教師の思考過程の言 語化は，援助策具体化に向けた試行錯誤を保護者と共有 することにつながり，連携を促進すると考えられた。

\section{筑波大学大学院人間総合科学研究科}

\section{博士（心理学） 瀬戸 美奈子}

「中学校・高校の援助チームおよび援助システムにおける コーディネーションに関する研究」

本研究では学校における援助チーム・援助システムの コーディネーションに関して，(1)具体的なコーディネー ション行動，(2)コーディネーターの能力および役割権限, (3)コーディネーション行動が援助チームの有用性や援助 システム活性化に与える影響について明らかにすること を目的とした。研究の結果, コーディネーション行動が チーム援助を促進し，コーディネーターの活動には能力 だけでなく，学校要因が影響していることが示唆された。

\section{筑波大学大学院人間総合科学研究科}

\section{博士（カウンセリング科学） 樽木 靖夫}

「協力的集団体験を通して中学生の自己評価を高める教 師の援助的介入に関する研究」

学校行事での協力的集団体験を通して中学生の自己評 価を高める教師の援助的介入について，「活動する小集 団の発達」「学級集団での分業的協力」の集団での協力 に関する生徒の認知を導入して検討した。教師による生 徒の葛藤解決への援助が「活動する小集団の発達」「学 級集団での分業的協力」を介して，生徒の自己活動，他 者との相互理解, 学級集団への理解の自己評価に影響し た。これらの結果より教師の援助について考察した。

\section{筑波大学大学院人間総合科学研究科 \\ 博士（心理学） 藤枝 静暁}

「子どもを対象としたソーシャルスキル教育プログラム の実践研究」

ソーシャルスキル教育プログラムとは，学校が主体と なり家庭と連携し，子どもにソーシャルスキルを習得さ せることを目的とした心理教育である。プログラムは， 学級単位の SST，対人関係ゲームの要素を取り入れた SST，家庭におけるSSTの 3 つで構成されている。効 果測定は，質問紙調査，ふり返りカード，教師へのイン タビュー, 保護者の感想を求める自由記述など多面的に 行われ，プログラムの効果が確認された。 


\section{筑波大学大学院人間総合科学研究科}

博士（カウンセリング科学） 山口 豊一

「中学校に扔けるマネジメント委員会の機能がチーム援 助体制及びチーム援助行動に与える影響」

中学校に打けるマネジメント委員会の機能を探索的に 明らかにし，そしてその機能がチーム援助体制及びチー ム援助行動にどのように影響するかを検討した。その結 果, マネジメント委員会が機能している学校は, チーム 援助体制及びチーム援助行動が促進されることが明らか になった。さらに, 学年主任等の主任層における検討で は，マネジメント委員会の「情報共有・問題解決」機能 がそれぞれに強く影響することが明らかになった。

\section{中央大学大学院文学研究科}

\section{博士（心理学） 岡田 有司}

「中学校への心理・社会的適応に関する学校心理学的研究 一適応の空間的側面・時間的側面の観点から一」

本研究では, 心理的適応・社会的適応の両側面から包 括的に学校適応を捉える枠組みを提示し, それに基づき 中学校への適応状態, 適応過程について検討した。その 結果, 学校適応を捉える際には「適応の支え」という視 点が重要であることが導かれ, 適応の支えには, (1)学校 生活への適応の基礎としての機能, (2)学校生活に対する 動機付けとしての機能, (3)学校生活において生じた損失 を補償するものとしての機能があることが示された。

\section{東京大学大学院教育学研究科}

\section{博士（教育学） 瀬尾 美紀子}

「学習上の援助要請の生起・回避㧍よび依存的援助要請に 対する影響要因一学習方略としての側面と援助者の指導 スタイルに着目した検討一」

学習上のつまずきを教師や友だちなどの他者に尋ねて 解消を試みる学習行動を, 学習上の援助要請と呼ぶ。本 論文では, 「援助要請の回避」と「依存的援助要請」の 問題がなぜ起こるのか, 影響要因を検討した。これらの 問題に対して, 学習者のメ夕認知的スキルとしてのつま ずき明確化方略使用の有無が関連していることが明らか になった。また, 依存的援助要請には, 学習者の学習観 と教師の指導スタイルが関連していることも示された。

\section{東京都立大学大学院人文科学研究科}

\section{博士 (心理学) 尾見 康博}

「好意・善意のディスコミュニケーション一文脈依存的 ソーシャル・サポート論の展開一」

本論文では, ソーシャル・サポート研究の理論的枠組 みを用いて，好意・善意のディスコミュニケーションの
多様なパターンを記述的に論考した。好意と善意のディ スコミュニケーションの生起にはコミュニケーション当 事者の関係性，そして外部の第三者の影響が大きいこと を明らかにし，好意と善意をコミュニケーションの当事 者に限定せずに開かれたシステムとして捉えることの意 義を論じた。

\section{法政大学大学院人文科学研究科}

\section{博士（心理学）原田 恵理子}

「高校生の自尊心にソーシャルスキルトレーニングが及 ぼす効果について」

本研究では高校生における自尊心の発達的特徵に基づ き，自尊心の獲得を目指す「感情の認知的側面」にアプ ローチしたソーシャルスキルトレーニングのプログラム を作成し，その効果を検討した。また，教師へのコンサ ルテーションと個別的支援が必要な生徒の面接をスクー ルカウンセラーが行う支援体制についても検討した。そ の結果, 向社会的行動の上昇と攻撃行動の減少，支援体 制への一定の効果を期待できることが明らかになった。

\section{名古屋大学大学院教育発達研究科}

\section{博士（心理学）斉田 智里}

「項目応答理論を用いた事後的等化法による英語学力の 経年変化に関する研究」

学力比較には共通尺度が不可欠である。等化デザイン で作成されていない日本の学力テストについて, 項目応 答理論を活用して事後的に等化する方法を示し，学習指 導要領改訂前後に実施された英語学力テストを共通尺度 化することができた。その結果, 高校入学時の英語学力 が年々低下していること，学力層により指導要領改訂前 後で低下の程度に差があることなどが明らかとなった。 デー夕に基づく教育効果検証の必要性について論じた。

\section{関西学院大学文学研究科}

\section{博士（教育心理学）石 晓玲}

「包括的モデルから捉えた日本と中国の育児期母親の ディストレス」

本論文は育児期母親の心身の健康への支援が重要であ ることを前提とし，母親のディストレスに影響する個人 差の要因を日本と中国において明らかにすることを目的 とした。ディストレスを生成する包括的モデルを示し， このモデルに内在する社会・歴史的アプローチ, 生態学 的アプローチ，および文化的アプローチから，有職の育 児期母親の日中比較研究を行った。それらの結果より, 育児期母親への支援の具体的な提案が見出された。 